\title{
Correction to: FXTAS is difficult to differentiate from neuronal intranuclear inclusion disease through skin biopsy: a case report
}

Megumi Toko ${ }^{1,2}$, Tomohiko Ohshita ${ }^{1,2^{*}}$, Takashi Kurashige ${ }^{3}$, Hiroyuki Morino ${ }^{2}, K^{\prime}$ odai Kume ${ }^{4,5}$, Hiroshi Yamashita ${ }^{1}$, Gen Sobue ${ }^{6}$, Yasushi Iwasaki ${ }^{7}$, Jun Sone ${ }^{7,8}$, Hideshi Kawakami ${ }^{4}$ and Hirofumi Maruyama ${ }^{2}$

\section{Correction to: BMC Neurol 21, 396 (2021)}

https://doi.org/10.1186/s12883-021-02425-z

Following publication of the original article [1], the authors reported that the captured corresponding author is not correct. The correct Corresponding author should be "Tomohiko Ohshita" and not "Megumi Toko".

The original article [1] has been updated.

\begin{abstract}
Author details
'Department of Neurology, Hiroshima City Asa Citizens Hospital, 2-1-1, Kabeminami, Asakita-ku, Hiroshima 731-0293, Japan. ${ }^{2}$ Department of Clinical Neuroscience and Therapeutics, Hiroshima University Graduate School of Biomedical and Health Sciences, 1-2-3 Kasumi, Minami-ku, Hiroshima 734-8553, Japan. ${ }^{3}$ Department of Neurology, National Hospital Organization Kure Medical Center and Chugoku Caner Center, 3-1 Aoyama-cho, Kure, Hiroshima 7370023, Japan. ${ }^{4}$ Department of Epidemiology, Research Institute for Radiation Biology and Medicine, Hiroshima University, 1-2-3 Kasumi, Minami-ku, Hiroshima 734-8553, Japan. ${ }^{5}$ Department of Supportive and Promotive Medicine of the Municipal Hospital, Faculty of Medicine, Kagawa University, 1750-1 Ikenobe Kagawa, Miki-cho, Kita-gun 761-0793, Japan. ${ }^{6}$ Aichi Medical University, Nagakute, Aichi, Japan. ${ }^{7}$ Department of Neuropathology, Institute for Medical Science of Aging, Aichi Medical University, Nagakute, Aichi 480-1195, Japan. ${ }^{8}$ Department of Neurology, National Hospital Organization Suzuka National Hospital, 3-2-1, Kasado, Suzuka, Mie 513-8501, Japan.
\end{abstract}

Reference

1. Toko M, Ohshita T, Kurashige T, et al. FXTAS is difficult to differentiate from neuronal intranuclear inclusion disease through skin biopsy: a case report. BMC Neurol. 2021;21:396. https://doi.org/10.1186/ s12883-021-02425-z.

\section{Publisher's Note}

Springer Nature remains neutral with regard to jurisdictional claims in published maps and institutional affiliations.

Published online: 27 October 2021

The original article can be found online at https://doi.org/10.1186/s12883021-02425-z.

\footnotetext{
*Correspondence: ohshita4@hiroshima-u.ac.jp

${ }^{2}$ Department of Clinical Neuroscience and Therapeutics, Hiroshima

University Graduate School of Biomedical and Health Sciences, 1-2-3

Kasumi, Minami-ku, Hiroshima 734-8553, Japan

Full list of author information is available at the end of the article
}

(C) The Author(s) 2021. Open Access This article is licensed under a Creative Commons Attribution 4.0 International License, which permits use, sharing, adaptation, distribution and reproduction in any medium or format, as long as you give appropriate credit to the original author(s) and the source, provide a link to the Creative Commons licence, and indicate if changes were made. The images or other third party material in this article are included in the article's Creative Commons licence, unless indicated otherwise in a credit line to the material. If material is not included in the article's Creative Commons licence and your intended use is not permitted by statutory regulation or exceeds the permitted use, you will need to obtain permission directly from the copyright holder. To view a copy of this licence, visit http://creativecommons.org/licenses/by/4.0/. The Creative Commons Public Domain Dedication waiver (http://creativecommons.org/publicdomain/zero/1.0/) applies to the data made available in this article, unless otherwise stated in a credit line to the data. 